\title{
Marandu palisade grass intercropped with densely spaced teak in silvopastoral system
}

\section{Capim-Marandu consorciado com Teca adensada em sistema silvipastoril}

\author{
Carlos Eduardo Avelino Cabral ${ }^{1 *}$; Lívia Vieira de Barros²; \\ Joadil Gonçalves de $\mathrm{Abreu}^{2}$; Felipe Gomes da Silva²; Carla Heloisa Avelino \\ Cabral $^{1}$; Arthur Behling Neto ${ }^{3}$; Flávio Cunha Ferreira Andrade ${ }^{4}$; Kyron Cabral \\ Sales $^{5}$; Dayenne Mariane Herrera ${ }^{5}$ Thainara Matilde Muniz Dellarmelinda ${ }^{6}$
}

\begin{abstract}
This study was conducted to evaluate two systems of production: integration between teak and forage (silvopastoral system) and forage only (monoculture). The forage species used was Marandu palisade grass (Urochloa brizantha cv. Marandu). In January 2009, part of the pasture was desiccated and the teak (Tectona grandis) was implemented in a $3 \times 4 \mathrm{~m}$ spacing arrangement, and at every five rows, a space between rows of $6 \mathrm{~m}$ was established, providing a population of 750 trees per hectare. Alongside the development of the trees, the Marandu palisade grass pasture was reestablished. In February 2015, the animals were removed from the experimental area and, in March, the pasture degradation, the density and the mass of tillers was assessed. The following variables were evaluated: sward height; forage mass, percentage of leaf blade, stem+sheath and senescent material; leaf blade:stem+sheath ratio; and live:dead material ratio. The experimental design was completely randomized, with 12 replicates. Treatments consisted of two systems (silvopastoral and monoculture). The total forage accumulation was higher in the monoculture system. The sward height and the percentage of stem+sheath were higher in the integrated system, while the percentage of leaf blade and the leaf blade:stem+sheath ratio were higher in the system exclusively with forage. In conclusion, Marandu palisade grass tolerates shading in a high density spacing silvopastoral system, but the degradation process is more intense compared to grass in monoculture, and the use of Marandu palisade grass in silvopastoral systems changes the forage mass and the structure of the produced forage.
\end{abstract}

Key words: Forage participation. Shading. Soil cover. Tectona grandis. Urochloa brizantha.

\section{Resumo}

Este trabalho foi realizado para avaliar dois sistemas de produção: integração entre teca e forragem (silvipastoril) e somente forragem (monocultivo). A forrageira utilizada foi o capim-Marandu. Em janeiro de 2009, parte do pasto foi dessecado e implantou-se Teca (Tectona grandis) em espaçamento de 3 x $4 \mathrm{~m}$

${ }^{1}$ Profs. Drs., Universidade Federal de Mato Grosso, UFMT, Rondonópolis MT, Brasil. E-mail: carlos.eduardocabral@hotmail. com; cabralcha@hotmail.com

${ }^{2}$ Profs. Drs., UFMT, Cuiabá, MT, Brasil. E-mail: liviavieiradebarros@gmail.com; joadil@terra.com.br; felipe.melhoramento@ gmail.com

3 Prof. Dr., UFMT, Sinop, MT, Brasil. E-mail: arthur_behling@hotmail.com

${ }^{4}$ Zootecnista, UFMT, Cuiabá, MT, Brasil. E-mail: flavio_andrade@hotmail.com

${ }^{5}$ Discentes, Curso de Mestrado do Programa de Pós-Graduação em Agricultura Tropical, UFMT, Cuiabá, MT, Brasil. E-mail: cabral.zootecnia@hotmail.com; dayenne.herrera@gmail.com

6 Discente, Graduação em Zootecnia, UFMT, Cuiabá, MT, Brasil. E-mail: munizthainara@hotmail.com

* Author for correspondence 
e a cada cinco linhas estabeleceu-se um espaçamento de $6 \mathrm{~m}$ entre linhas, o que garantiu uma população de 750 árvores por hectare. Paralelamente ao desenvolvimento das árvores houve o restabelecimento do pasto de capim-Marandu. Em fevereiro de 2015, retirou-se os animais da área e em março avaliou-se o estádio de degradação do pasto, a densidade e a massa de perfilhos. Avaliou-se também a altura do dossel forrageiro, a massa de forragem e as porcentagens de: lâmina foliar, colmo+bainha e material morto, a relação lâmina foliar/colmo+bainha e a relação vivo/não vivo. O delineamento experimental foi inteiramente casualizado, com dois tratamentos (silvipastoril e monocultivo) e doze repetições. A massa de forragem foi maior no sistema com monocultivo de capim-Marandu. A altura da forragem e a porcentagem de colmo + bainha foram maiores no sistema silvipastoril, já a porcentagem de lâmina foliar e a relação lâmina:colmo+bainha foram maiores para o sistema com monocultivo. Conclui-se que o capim-marandu tolera o sombreamento em sistema silvipastoril adensado, contudo o processo de degradação é mais intenso do que o capim em monocultivo e a utilização do capim-Marandu em sistemas silvipastoris altera a massa de forragem e a estrutura da forragem produzida.

Palavras-chave: Cobertura do solo. Participação forrageira. Sombreamento. Tectona grandis. Urochloa brizantha.

\section{Introduction}

The need for environmental preservation and the current legislation have imposed limits for agricultural production. In this context, beef cattle production needs to undergo adaptations in its production system, since this activity is a great user of natural resources. Brazil has the second largest herd of bovines in the world, with most of the livestock production carried out on pasture and with low general indexes of production. Therefore, production verticalization is a desired tendency, in order to obtain higher yield and profit per hectare. One solution is to use integrated production systems, such as silvopastoralism, which consists in the integration of trees, pasture and animals in the same area and period. Silvopastoral systems, when well established and correctly managed, allow the optimization of the use of resources with the potential for sustainable agricultural production from the economic and environmental point of view.

Analyzing the demands of modern society related to the beef production system, Corsi and Goulart (2006) warned of the importance of environmental safety in the production process, involving: animal well-being, soil and water conservation, mitigation of greenhouse gases and carbon sequestration, and the provision of environmental services in pasture areas, demands that can be attained by the inclusion of the forest component in well-managed livestock systems.
Most of Brazil's beef cattle herds are located in the central-west and northern regions of the country, in climatic conditions that can cause thermal stress in medium and severe degrees at some periods of the year. In this context, since thermal comfort integrates the concept of animal well-being, which can influence the cattle's productive performance, animal suffering due to excessive heat from the environment should be avoided.

Therefore, shade with good quality is required for cattle raised on pasture, especially for taurine animals, which are less adapted to the tropical environment. The arboreal component changes the microclimate, influencing the moisture in the air and the soil, which may help to maintain the forage quality in the wet-dry transitional period, since with the milder temperature and a greater amount of water in the soil, there is green forage for a longer time. So, the use of a well-managed silvopastoral system is important to allow shaded areas for animals and also to improve the quality of the available forage.

For the establishment of a silvopastoral system, teak is an option that is highly appreciated by producers, even with its slow growth, due to its good facility for cutting, plowing and lamination, besides providing planted forest wood with a greater market value. In this sense, the condition evidenced by cattle raisers who adopt forestry is the desiccation of the pastures and the implementation of these trees. However, the re-establishment of forage has been 
observed in some locations, even among densely spaced trees, due to the lower competition for light when the seedlings are in the early development stage.

However, when the trees grow higher, there is competition for light, which can negatively affect the forage production. As an overall production system, the components of silvopastoral systems interact with one another, which may result in synergistic or antagonistic effects. So, the identification of forage species that can tolerate shading is required. Marandu palisade grass (Urochloa brizantha cv. Marandu) is the most extensive forage in Central Brazil, due to its good yield and nutritive value. Given the widespread use of Marandu palisade grass and the insertion of the arboreal component as a strategy to increase the animals' thermal comfort, the diversification of activities and the economic viability, it becomes relevant to determine if this forage can tolerate shading and if there is any change in its nutritive value. Thus, the goal was to investigate if there is any change in the production and nutritive value of Marandu palisade grass cultivated in a high density spacing silvopastoral system.

\section{Material and Methods}

The trial was conducted at a property in IndiavaíMT, (Latitude 15²7' South, Longitude 58 34' West, Altitude $194 \mathrm{~m})$. The region's climate, according to the Koeppen classification system, is Aw, indicating that it is tropical humid, with an average annual rainfall of $1,503 \mathrm{~mm}$. The experimental area consisted of 5 ha, cultivated with Marandu palisade grass pastures in monoculture and with an intercrop of teak and Marandu palisade grass, in a eutrophic red-yellow ultisol (SEPLAN, 2001). The experiment design was completely randomized, with 12 replicates. The treatments consisted of two production systems: integration between teak and Marandu palisade grass (silvopastoral) and exclusive grass (monoculture).

The Marandu palisade grass pasture was established in 1998. In January 2009, part of the pasture was desiccated and teak (Tectona grandis) was implanted with a spacing of $3 \mathrm{~m}$ between trees and $4 \mathrm{~m}$ between rows and, after every five, a space with $6 \mathrm{~m}$ between rows was established, which guaranteed a population of 750 trees per ha. Alongside the trees development, the Marandu palisade grass pasture was re-established. Pruning was performed when the trees were $7 \mathrm{~m}$ high. In January of 2015, thinning was carried out, removing $40 \%$ of the trees. There has never been any fertilization of the area.

For both treatments, the pastures were deferred in January 2015, and the beef cattle were removed when the average canopy height reached $30 \mathrm{~cm}$. Forty days later, chemical and granulometric characterization of the soil was performed (Table 1), as well as an evaluation of the forage production and pasture degradation. Evaluations were randomly done at twelve points (experimental plots) in each treatment, with measurement of the: grass height, forage mass, number and mass of tillers, Falker chlorophyll index, soil cover, forage participation and erosion.

Table 1. Chemical and granulometric characterization in the $0-20 \mathrm{~cm}$ layer of a eutrophic Red-Yellow Ultisol in Indiavaí, MT, 2015.

\begin{tabular}{|c|c|c|c|c|c|c|c|c|c|c|c|}
\hline $\mathrm{pH}$ & $\mathrm{P}$ & $\mathrm{K}$ & $\mathrm{Ca}$ & $\mathrm{Mg}$ & $\mathrm{Al}$ & $\mathrm{H}$ & $\mathrm{CEC}$ & $\mathrm{V}$ & Sand & Silt & Clay \\
\hline $\mathrm{CaCl}_{2}$ & \multicolumn{2}{|c|}{$\mathrm{mg} \mathrm{dm}^{-3}$} & \multicolumn{5}{|c|}{$\mathrm{cmol}_{c} \mathrm{dm}^{-3}$} & $\%$ & \multicolumn{3}{|c|}{$\mathrm{g} \mathrm{kg}^{-1}$} \\
\hline 5.55 & 11.3 & 78.0 & 3.4 & 0.6 & 0.0 & 1.9 & 6.1 & 69.0 & 715 & 89 & 196 \\
\hline
\end{tabular}

CEC: cation exchange capacity; V: base saturation. 
The canopy height was measured with a graduated ruler. The forage mass was estimated by sampling using a square with $0.5 \mathrm{~m}$ sides, considering a height of $20 \mathrm{~cm}$. After cutting, the grass fractions (leaf blade, stem + sheath and dead material) were separated. The tiller density was estimated using a square with $0.30 \mathrm{~m}$ sides. The tiller mass was obtained by the average weight of 30 tillers per experimental plot. The Falker chlorophyll index was determined with readings in five newly expanded leaves per experimental plot, using a ClorofiLOG® chlorophyllometer model CFL 1030. The evaluation of the pasture degradation considered the dry green mass production, forage participation, soil cover and presence of erosion, as described by Bauer et al. (2004).

The forage and tillers samples were submitted for drying in an air circulation oven at $55 \pm 5^{\circ} \mathrm{C}$ for 72 hours. Pre-dried samples were weighed, and then ground in a Wiley mill until they could pass through a $1 \mathrm{~mm}$ steel sieve. The samples were submitted for estimates of dry matter (DM), crude protein (CP) and mineral matter (MM), according to AOAC (2000); neutral detergent fiber (NDF), according to Mertens (2002). The content of nitrogen insoluble in neutral detergent (NIDN) and acid detergent fiber content (ADF) (VAN SOEST; ROBERTSON, 1985) was quantified. The indigestible neutral detergent fiber (iNDF) was estimated as described by Valente et al. (2011).

Potentially digestible dry matter (pdDM) was estimated according to the following equation (PAULINO et al., 2008):

$\operatorname{pdDM}=0.98 \times(100-N D F a p)+($ FNDFap-iNDF $)$.

where: NDFap: neutral detergent fiber corrected for ash and protein. iNDF: indigestible neutral detergent fiber.

For all the evaluated variables, analysis of variance and Pearson's correlation between the Falker chlorophyll index and the crude protein content was performed, considering, for both analyses, a $5 \%$ probability of error.

\section{Results and Discussion}

Regarding the production and morphological composition, there were differences in all the evaluated variables for the systems, except for the percentage of dead material and the live:dead ratio (Table 2). The forage mass was higher in the monoculture of Marandu palisade grass. This difference can be attributed to the most favorable conditions for dry mass accumulation in this system, since in the silvopastoral system there was more intense shading, which implies a reduction in the quantity and quality of light. Similarly, Sousa et al. (2007) observed a reduction in the production of Urochloa brizantha shaded by Zeyheria tuberculosa. Paciullo et al. (2007) observed lower production of Urochloa decumbens in a shaded environment. However, after thinning $30 \%$ of the trees, the same production was observed in the shaded environment compared to full sun (monoculture). The lower forage accumulation in the silvopastoral system can be attributed to the fact that tropical forages, such as Marandu palisade grass, are plants with a C4 metabolism, which allows a greater productive response to light energy.

Even though the lowest production occurred in the silvopastoral system, a greater participation of stem+sheath was observed in this condition. The shading increases the elongation rate of the stems, which can be observed by the greater height of the forage (Table 2) in the shaded condition, this being an adaptive mechanism to increase the amount of light intercepted under limiting conditions (COELHO et al., 2014). The stretching of plants under shading is a mechanism by which the plant seeks light by raising its leaves in the canopy. In grasses, this mechanism allows a better distribution of the radiation along the canopy profile (GOMIDE et al., 2007). Possibly, therefore, a lower participation of leaf blades was observed in the silvopastoral system, since the plants prioritized the development of stem + sheath. The reduction in the leaf blade:stem ratio (LSR) is a characteristic of canopies at a more advanced stage of development, in which increased shading and 
competition among plants within the canopy results in a greater accumulation of stems and a consequent reduction in LBR (COELHO et al., 2014), which happened in this study and was reflected in a lower LBR for the shaded environment (Table 2).

Table 2. Forage height and production, percentage of leaf blade, stem + sheath and dead material, leaf blade:stem + sheath ratio and live:dead material ratio of Marandu palisade grass in monoculture and silvopastoral system.

\begin{tabular}{lccccccc}
\hline \multirow{2}{*}{ Treatment } & Height & Forage mass & LB & SS & DM & LSR & LDR \\
\cline { 2 - 8 } & $\mathrm{cm}$ & $\mathrm{tha}^{-1}$ & & $\%$ & & - & - \\
\hline Monoculture & $67 \mathrm{~b}$ & $3.27 \mathrm{a}$ & $54 \mathrm{a}$ & $28 \mathrm{~b}$ & $18 \mathrm{a}$ & $2.01 \mathrm{a}$ & $4.69 \mathrm{a}$ \\
Silvopastoral & $82 \mathrm{a}$ & $2.58 \mathrm{~b}$ & $49 \mathrm{~b}$ & $34 \mathrm{a}$ & $17 \mathrm{a}$ & $1.44 \mathrm{~b}$ & $5.51 \mathrm{a}$ \\
CV(\%) & 10.59 & 33.33 & 12.57 & 9.55 & 27.8 & 23.79 & 35.81 \\
\hline
\end{tabular}

Means followed by the same letter, in the column, did not differ among themselves by the F test ( $p>0.05)$. LB: leaf blade; SS: stem + sheath; DM: dead material; LSR: leaf blade:stem+sheath ratio; LDR: live:dead material ratio.

Senescence is also a phenomenon evidenced in forages with advanced development, but in this study there was no difference in the percentage of dead material and in the live:dead material ratio between the Marandu palisade grass monoculture system and the silvopastoral system (Table 2). Stem elongation and the increase of the senescent material occur after the moment when the canopy intercepts $95 \%$ of the light radiation. Thus, it can be seen that forage plants have the capacity to modify the canopy structure as an adaptation for shaded conditions (phenotypic plasticity), so that even with a greater height $(82 \mathrm{~cm})$, only the increase of stem+sheath was observed, with the same proportion of senescent material.

Regarding the littering study and the evaluation of grass degradation, differences were observed between the two systems for all the evaluated variables except for erosion (Table 3 ). In the Marandu palisade grass in monoculture, a higher density of tillers was observed, but the tillers were lighter. The quantity and quality of light both influence tillering, once the red radiation estimates the phytochrome production, a pigment that interferes in the tiller emission. The Marandu palisade grass in monoculture presented a lower pasture height, which promotes greater light penetration into the canopy and alters the pasture structure, due to increase in the red / far-red ratio at the base of the plant, incrementing the tillering (CASAL et al., 1985). Martuscello et al. (2009) observed a decrease in the number of Marandu palisade grass tillers with increase of shading, which corroborates the present study.

Table 3. Density and mass of tillers, forage participation (FORR), soil cover (COV), forage dry mass (FDM), erosion in Marandu palisade grass pastures in monoculture and silvopastoral system.

\begin{tabular}{|c|c|c|c|c|c|c|}
\hline \multirow{2}{*}{ Treatment } & \multicolumn{2}{|c|}{ Tillers } & FORR* & $\mathrm{COV}^{*}$ & FDM & Erosion* \\
\hline & $\mathrm{n}^{\mathrm{o}} \mathrm{m}^{-2}$ & $\mathrm{~g}_{\mathrm{g} \text { tiller }}{ }^{-1}$ & & & $\mathrm{~kg} \mathrm{ha}^{-1}$ & - \\
\hline Monoculture & $510 \mathrm{a}$ & $1.37 \mathrm{~b}$ & $99 \mathrm{a}$ & $97 \mathrm{a}$ & $2.630 \mathrm{a}$ & Null \\
\hline Silvopastoral & $430 \mathrm{~b}$ & $1.58 \mathrm{a}$ & $88 \mathrm{~b}$ & $66 \mathrm{~b}$ & $2.140 \mathrm{~b}$ & Null \\
\hline CV $(\%)$ & 14.98 & 16.46 & 12.79 & 15.93 & 30.78 & - \\
\hline
\end{tabular}

Means followed by the same letter, in the column, did not differ among themselves by the F test ( $\mathrm{p}>0.05)$. ${ }^{*}$ Qualitative Visual Assessment, according to Bauer et al. (2004). 
Lower soil cover was observed in the silvopastoral system, which is explained by the lower density of tillers, due to shading. This lower soil cover promotes greater emergence of weeds, which reduce the forage participation, also evidenced in this study. However, even in low soil cover $(66 \%)$ and with lower forage participation, a high participation of weed was not observed in the silvopastoral system (12\%), since the shading itself suppresses the development of the grass as much as the weeds. In this perspective, uncovered soil without forage or weeds has a great predisposition to erosion, which was not evidenced, since there was no erosion in either system. The absence of soil loss is possibly due to the synergistic effect of the teak vegetation cover, which reduces the kinetic energy of rainfall, as well as the beneficial effect of the organic matter from the litter decomposition, which increases the soil aggregates stability (ROZANE et al., 2010).

The pasture in monoculture is in excellent condition (BAUER et al., 2004), since it was possible to observe a green dry mass production of more than 2,500 $\mathrm{kg} \mathrm{ha}^{-1}$, forage participation and soil cover greater than $75 \%$ and absence of erosion. It is recommended for pastures in this condition only to adjust the stocking rate according to the support capacity and to carry out periodic maintenance fertilization with nitrogen only, since the soil phosphorus and potassium contents are adequate (SOUSA et al., 2007). On the other hand, the pasture in the silvopastoral system fits the excellent-good transition (BAUER et al., 2004), considering that the production of green dry mass is between 1,500 and $2,500 \mathrm{~kg} \mathrm{ha}^{-1}$ and the soil cover is between 50 and $75 \%$. Faced with this panorama, in addition to the recommendations for monoculture systems, control of weeds and termites should be performed, with the latter not being evidenced in the area.

Considering that Marandu palisade grass has been present in the area since 1998 and intercropped with teak since 2009, its relative tolerance to shading in this forage is evident. The continuous growth of the trees and the intensification of shading over the years, even with the thinning, have probably resulted in a slow degradation of the pasture. If the degradation process accelerates, renewal of the pasture in a high density spacing tree system will not succeed, since there will be an impediment, due to the spacing between trees, which makes mechanization impossible. In addition, the excess of shade prevents the initial development of the forage, minimizing the production and the tillering.

As for the chemical composition, the forage in the silvopastoral system presented higher levels of ADF and iNDF, which resulted in lower potentially digestible dry matter (pdDM) (Table 4). The lower pdDM in the silvopastoral system was due to the higher proportion of stem, with lower digestibility (DESCHAMPS, 1999) due to the greater amount of indigestible tissues, such as xylem and sclerenchyma (PACIULLO, 2002).

On the other hand, the Marandu palisade grass in the silvopastoral system presented higher levels of ash, crude protein, NDIP (\% DM and\% CP) and Falker chlorophyll index (FCI), compared to the monoculture. Even with a higher proportion of stem + sheath in the silvopastoral system, a higher crude protein content was obtained, which may be associated with the high content on leaf blades, since Paciullo et al. (2007) also observed higher crude protein content in a shaded environment, due to the higher concentration of crude protein in the leaf blades. However, in the dense spacing system, the Marandu palisade grass had a higher protein content associated with the cell wall (NDIP), which may reduce the use of this protein. Despite the hypothesis that in shaded systems there occurs a lower content of nitrogen associated with the cell wall, it was not possible to verify this, possibly due to the high participation of stem +sheath in the morphological composition of the forage. Another relevant aspect is that the area has never been fertilized so the nitrogen assimilation possibly occurred through decomposition of the litter, which provides nutrients for the grass. 
Table 4. Chemical composition of Marandu palisade grass in silvopastoral and monoculture system.

\begin{tabular}{|c|c|c|c|}
\hline \multirow{2}{*}{ Variable * } & \multicolumn{2}{|c|}{ Treatments } & \multirow{2}{*}{$\mathrm{CV}(\%)$} \\
\hline & Silvopastoral & Monoculture & \\
\hline pdDM (\%) & $77.09 \mathrm{~B}$ & $80.20 \mathrm{~A}$ & 3.61 \\
\hline pdDM (t ha-1) & $1.97 \mathrm{~B}$ & $2.59 \mathrm{~A}$ & 31.12 \\
\hline Ashs (\%) & $10.16 \mathrm{~A}$ & $9.45 \mathrm{~B}$ & 6.38 \\
\hline NDF (\%) & $65.15 \mathrm{~A}$ & $65.69 \mathrm{~A}$ & 2.65 \\
\hline $\operatorname{ADF}(\%)$ & $44.08 \mathrm{~A}$ & $41.10 \mathrm{~B}$ & 4.61 \\
\hline iNDF(\%) & $22.20 \mathrm{~A}$ & $19.10 \mathrm{~B}$ & 13.79 \\
\hline Crude protein $(\%)$ & $8.26 \mathrm{~A}$ & $5.66 \mathrm{~B}$ & 11.23 \\
\hline NDIP (\% DM) & $1.74 \mathrm{~A}$ & $0.87 \mathrm{~B}$ & 20.88 \\
\hline NDIP (\% CP) & $20.32 \mathrm{~A}$ & $15.64 \mathrm{~B}$ & 14.04 \\
\hline FCI & $42.80 \mathrm{~A}$ & $35.60 \mathrm{~B}$ & 6.98 \\
\hline
\end{tabular}

Means followed by the same capital letter, in the line, did not differ among themselves by the $\mathrm{F}$ test ( $>0.05)$. * pdDM: potentially digestible dry matter; NDF: neutral detergent fiber; ADF: acid detergent fiber; iNDF: indigestible neutral detergent fiber; NDIP: neutral detergent insoluble protein; FCI: Falker chlorophyll index.

The shaded Marandu palisade grass obtained higher FCI, which shows that this index was satisfactory to indicate the system with the higher crude protein content. Even with a significant correlation between this index and the crude protein content in the forage, the correlation coefficient ( $r=0.58)$ was low, which may be due to the fact that the readings were taken in the leaf blades and the pasture had a high proportion of stem + sheath, which contributes to modifying the crude protein content of the pasture. Thus, although the index demonstrates which system has the highest crude protein content, there is still insufficient accuracy to estimate the value of the crude protein in the forage.

More studies should be done to find a management height for Marandu palisade grass in a shaded system, considering that the forage plant changes its physiology of growth due to the reduced light supply, so it is necessary to find the optimal points for the forage harvest, seeking better animal performance and aiming to avoid degradation of the pasture.

\section{Conclusions}

The production and nutritive value of the Marandu palisade grass are affected by the shading provided by the silvopastoral system. The shading reduces the production and increases the height of the Marandu palisade grass in a densely spaced silvopastoral system, so that the stretching entails a lower potential for digestion.

\section{References}

ASSOCIATION OF OFFICIAL ANALYTICAL CHEMISTS - AOAC. Official methods of analysis of the Association of Official Analytical Chemists. $17^{\text {th }}$ ed. Washington: AOAC International Method, 2000.

BAUER, M. O.; SOUZA, A. L.; DOMINGUES, A. N. Recuperação de pastagens. Cuiabá: SENAR/MT, 2004. $88 \mathrm{p}$.

CASAL, J. J.; DEREGIBUS, A. V.; SANCHEZ, R. A. Variation in tiller dynamics and morphology in Lolium multiflorum vegetative and reproductive plants as affected by differences in red/far-red irradiation. Annals of Botany, Exeter, v. 56, n. 1, p. 553-559, 1985.

COELHO, J. S.; ARAUJO, S. A. C.; VIANA, M. C. M.; VILLELA, S. D. J.; FREIRE, F. M.; BRAZ, T. G. S. Morfofisiologia e valor nutritivo do capim-braquiária em sistema silvipastoril com diferentes arranjos espaciais. Semina: Ciências Agrárias, Londrina, v. 35, n. 3, p. 1487-1500, 2014. 
CORSI, M.; GOULART, R. O sistema de produção de carne e as exigências da sociedade moderna. In: SIMPÓSIO SOBRE MANEJO DA PASTAGEM, AS PASTAGENS E O MEIO AMBIENTE, 23., 2006, Piracicaba. Anais... Piracicaba: FEALQ, 2006. p. 7-35.

DESCHAMPS, F. C. Implicações do período de crescimento na composição química e digestão dos tecidos de cultivares de capim-elefante (Pennisetum purpureum Schumach.). Revista Brasileira de Zootecnia, Viçosa, MG, v. 28, n. 6, p. 1358-1369, 1999.

GOMIDE, C. A. M.; GOMIDE, J. A.; ALEXANDRINO, E. Características estruturais e produção de forragem em pastos de capim-mombaça submetidos a períodos de descanso. Pesquisa Agropecuária Brasileira, Brasília, v. 42, n. 10, p. 1487-1494, 2007.

MARTUSCELLO, J. A.; JANK, L.; GONTIJO NETO, M. M.; LAURA, V. A.; CUNHA, D. N. F. V. Produção de gramíneas do gênero Uruchloa sob níveis de sombreamento. Revista Brasileira de Zootecnia, Viçosa, MG, v. 38, n. 7, p. 1183-1190, 2009.

MERTENS, D. R. Gravimetric determination of amylasetreated neutral detergent fiber in feeds with refluxing in beakers or crucibles: collaborative study. Journal of AOAC International, Rockville, v. 85, n. 6, p. 1217-1240, 2002.

PACIUllo, D. C. S.; CARVAlho, C. A. B. D.; AROEIRA, L. J. M.; MORENZ, M. J. F.; LOPES, F. C. F.; ROSSIELLO, R. O. P. Morfofisiologia e valor nutritivo do capim-braquiária sob sombreamento natural e a sol pleno. Pesquisa Agropecuária Brasileira, Brasília, v. 42, n. 4, p. 573-579, 2007.

PACIULLO, D. S. C. Características anatômicas relacionadas ao valor nutritivo de gramíneas forrageiras. Ciência Rural, Santa Maria, v. 32, n. 2, p. 357-364, 2002.
PAULINO, M. F.; DETMANN, E.; VALADARES FILHO, S. C. Bovinocultura funcional nos tópicos. In: SYMPOSIUM ON STRATEGIC MANAGEMENT OF PASTURE, 4., 2008, Viçosa, MG. Proceedings... Viçosa, MG: Departamento de Zootecnia, UFV, 2008. p. 275305.

ROZANE, D. E.; CENTURION, J. F.; ROMUALDO, L. M.; TANIGUCHI, C. A. K.; TRABUCO, M.; ALVES, A. U. Estoque de carbono e estabilidade de agregados de um Latossolo Vermelho distrófico, sob diferentes manejos. Bioscience Journal, Uberlândia, v. 26, n. 1, p. 24-32, 2010.

SECRETARIA DO ESTADO DE PLANEJAMENTO E COORDENAÇÃO GERAL - SEPLAN. Mapa de solos do Estado do Mato Grosso. Cuiabá: SEPLAN-MT, 2001. Mapa Temático. Escala 1:250.000.

SOUSA, L. F.; MAURÍCIO, R. M.; GONÇALVES, L. C.; SALIBA, E. O. S.; MOREIRA, G. R. Produtividade e valor nutritivo da Urochloa brizantha cv. Marandu em um sistema silvipastoril. Arquivo Brasileiro de Medicina Veterinária e Zootecnia, Belo Horizonte, v. 59, n. 4, p. 1029-1037, 2007.

VALENTE, T. N. P.; DETMANN, E.; QUEIROZ, A. C.; VALADARES FILHO, S. C.; GOMES, D. I.; FILGUEIRAS, J. F. Evaluation of ruminal degradation profiles of forages using bags made from different textiles. Revista Brasileira de Zootecnia, Viçosa, MG, v. 40, n. 11, p. 2565-2573, 2011.

VAN SOEST, P. J.; ROBERTSON, J. B. Analysis of forages and fibrous foods. Ithaca: Cornell University, 1985. $202 \mathrm{p}$. 